\title{
Nutritional Composition, Techno-Functional Properties and Sensory Analysis of Pan Bread Fortified with Kenaf Seeds Dietary Fibre
}

(Komposisi Pemakanan, Sifat Tekno-Fungsi dan Analisis Sensori Roti Pan Diperkaya dengan Serat Pemakanan Biji Kenaf)

\author{
Nurul AinaA Farhanah Mat Ramlan, Salma Malihah Mohammad, Roselina Karim, Sharifah \\ KHARIDAH SYED MUHAMMAD, MAZNAH ISMAIL \& NORHASNIDA ZAWAWI*
}

\begin{abstract}
Kenaf seeds are underutilized source of food with good source of dietary fiber, protein, essential oil, and phytocompounds. The objectives of this study were to determine the nutritional composition of kenaf seeds, the technofunctional properties of kenaf seeds dietary fibre (KSDF), and sensory analysis of pan bread fortified with dietary fibre that was extracted from kenaf seeds. Analyses showed that kenaf seeds are rich in dietary fibre (28.87 g/ $100 \mathrm{~g})$, protein $(27.07 \mathrm{~g} / 100 \mathrm{~g})$, oil $(23.78 \mathrm{~g} / 100 \mathrm{~g})$ and mineral $(5.55 \mathrm{~g} / 100 \mathrm{~g})$. The dietary fibre that was extracted through enzymatic hydrolysis $(K S D F(E H))$ exhibited significantly $(p<0.05)$ greater water-binding capacity (WBC), oil-binding capacity $(O B C)$ and viscosity than non-enzymatic hydrolyzed kenaf seeds dietary fibre (KSDF (NEH)) and defatted kenaf seed meal (DKSM). Different formulations of bread were prepared by replacing $10 \%$ of wheat flour with wheat bran fibre (positive control), rice bran fibre and KSDF, with white bread unfortified with fibre as negative control. Addition of $10 \%$ KSDF to bread formulation significantly $(p<0.05)$ reduced bread height, volume, specific volume, water activity and firmness, and increased proofing time and bread surface colour. Results from the sensory evaluation of the bread samples also showed that KSDF bread was the most acceptable in comparison to rice bran and wheat bran fortified breads. This study shows that kenaf seed has valuable source of dietary fibre with the potential to be used as a functional ingredient in the development of functional breads.
\end{abstract}

Keywords: Functional food; kenaf seeds; physical properties; sensory evaluation; shelf-life

\section{ABSTRAK}

Biji kenaf adalah sumber makanan yang kurang digunakan serta merupakan punca serat, protein, minyak pati dan sebatian fito yang baik. Objektif kajian ini adalah untuk menentukan komposisi pemakanan biji kenaf, sifat tekno-fungsian serat dietari biji kenaf (KSDF) dan analisis sensori roti pan yang diperkaya dengan serat dietari yang diekstrak daripada biji kenaf. Analisis menunjukkan bahawa biji kenaf kaya dengan serat dietari (28.87 g/ $100 \mathrm{~g})$, protein (27.07 g/ 100 g), lemak (23.78 g/ $100 \mathrm{~g})$ dan mineral $(5.55 \mathrm{~g} / 100 \mathrm{~g})$. Serat dietari yang diekstraksi melalui hidrolisis enzim (KSDF $(E H))$ menunjukkan keupayaan mengikat air (WBC), kapasiti mengikat minyak (OBC) dan kelikatan yang lebih ketara daripada serat dietari biji kenaf melalui hidrolisis bukan menggunakan enzim (KSDF (NEH)) dan benih kenafyang telah dinyahlemak (DKSM). Formulasi roti yang berbeza disediakan dengan menggantikan 10\% tepung gandum dengan serat dedak gandum (kawalan positif), serat dedak beras dan KSDF, dengan roti putih yang tidak diperkaya dengan serat sebagai kawalan negatif. Penambahan 10\% KSDF ke dalam formulasi roti mengurangkan ketinggian, isi padu, isi padu tertentu, aktiviti air, kekerasan dan waktu kenaikan doh serta warna permukaan roti secara signifikan (p<0.05). Hasil daripada penilaian sensori sampel roti juga menunjukkan bahawa roti KSDF adalah yang paling diterima berbanding dengan roti yang difortikasi dengan bran beras dan gandum. Kajian ini menunjukkan biji kenaf tinggi dengan serat dietari yang berharga dengan potensi untuk digunakan sebagai ramuan berfungsi dalam penghasilan roti fungsian.

Kata kunci: Biji kenaf; jangka hayat; makanan fungsian; penilaian sensori; sifat fizikal

\section{INTRODUCTION}

At present, the rate of new cases of cardiovascular diseases (CVDs) is on the rise at an alarming rate. According to World Health Organization (WHO) (2017), CVDs are first cause of death globally where the estimation of people died from CVDs each year is about 17.9 million. CVDs 
are disease related to abnormality of the blood vessels that supply to the brain, heart and the clotting in blood vessels (Beyer 2016; World Health Organization 2017). WHO also stated that severe incidents of heart attacks and stroke are due to the clotting of blood vessels to the brain and heart and thus outlined preventive measures such as maintaining a healthy lifestyle by consuming a balanced diet, exercising regularly and stop smoking, as well as investigated effectiveness of medications and therapies to treat CVDs and colon cancer.

In order to consume a balanced diet, a healthy diet should be rich in fibre. There are many papers that reported on the high nutritional value of dietary fibre over the years and it is mostly accepted that dietary fibre is related with the prevention of various diet-related chronic (Kendall et al. 2010; Timm \& Slavin 2008). Dietary fibre give many health values towards the consumers as it helps in blood glucose and cholesterol reduction, improved gut health and intestinal function as well as protection against cardiovascular diseases and colon cancer (Dahl \& Stewart 2015). Increased consumer awareness has raised the demand for the advancement of dietary fibre-rich food products and brought attention to capability of dietary fibres as a functional ingredient in food.

Kenaf plant or Hibiscus cannabinus L., belonging to the mallow family (Malvaceae) is a plant indigenous to subtropical and tropical regions of Africa and Asia. It has become one of the potential industrial crops for the commodity in Malaysia (Ayadi et al. 2017). Since cultivation has started here since over many years ago, the crop has garnered positive reaction among farmers especially those who cultivated tobacco because plantation of kenaf is more environmentally friendly in comparison to tobacco. Widely grown since 4000 B.C. in sub-Saharan Africa (Dempsey 1975), every different parts of kenaf has been used widely for human consumption, animal food, handicraft making material as well as source of fuel. Kenaf planting has been done in many other countries like in India, Bangladesh, Thailand, and to a small area in southeast Europe for a long time (Saba et al. 2015). National Kenaf and Tobacco Board (NKTB) in Malaysia is a governing body with the goal to develop kenaf to become the country's third major commodity after oil palm and rubber. However, in the kenaf industry not every parts of the plant are fully exploited including kenaf seeds. According to Mat Daham et al. (2015), only 30\% of kenaf seeds are used for cultivation of new plants and the rest goes to waste.

In order to minimize the wastage of kenaf seeds that had always been misspent, intense research has been done to fully utilize kenaf plants especially kenaf seeds' oil and protein (Chan et al. 2013; Cheng et al. 2004; Ghafar et al. 2013; Mariod et al. 2010; Mohamed et al. 1995; Olawepo et al. 2014). However, studies on kenaf seeds dietary fibre (KSDF), its nutritional composition and functional characteristics are limited. The possibilities of using kenaf seeds as a source of dietary fibre is often neglected because mostly kenaf is considered as a source of fibre and feed crop. These abandoned kenaf seeds actually have high nutritional value especially in dietary fibre content which has been reported to be $13.6 \%$ (Nyam et al. 2009). Thus, this research was carried out to maximize the utilization of kenaf seeds.

In this study, kenaf seeds were used as an alternative source of dietary fibre in bread. Extracted dietary fibre from kenaf seeds is added into pan bread to improve its functional and nutritional values and sensory evaluation were carried out to assess the acceptance level compared to other breads.

\section{MATERIALS AND METHOdS}

\section{SAMPLE PREPARATION}

Kenaf seeds (variety V36) have been purchased from the National Kenaf and Tobacco Board, Pasir Putih, Kelantan, Malaysia by the Laboratory of Molecular and Biomedicine, Institute of Bioscience for the study. Kenaf seeds was prepared by washed with tap water for $10 \mathrm{~min}$, rinsed twice with distilled water, and air dried in an oven (FD 115, Fisher Scientific, Loughborough, Leicestershire, UK) at $50{ }^{\circ} \mathrm{C}$ overnight. Using a blender (Waring, Torrington, CT, USA) at a high speed for approximately $2 \mathrm{~min}$, dried kenaf seeds were pulverized, then screened with a $0.5 \mathrm{~mm}$ sieve, and lastly packed and stored at cool and dry conditions until further characterization (Chan et al. 2013).

\section{PROXIMATE ANALYSES OF KENAF SEEDS}

Moisture content was determined according to AOAC Method 934.01. Ash was examined gravimetrically by incineration of samples in a muffle furnace for $8 \mathrm{~h}$ at $550{ }^{\circ} \mathrm{C}$. The protein content was determined by using Kjeldahl method on a Kjeltec 2200 Analyzer unit (FOSSTecator AB, Hoganas, Sweden) and estimated as \% nitrogen $\times 6.25$ (conversion factor) which is consistent with AOAC method 978.04. Fat content was measured by following AOAC Method 991.36 assisted by Soxtec ${ }^{\text {TM }}$ 2050 Auto Fat Extraction System. Digestible carbohydrate was determined by calculation. 
DETERMINATION OF TOTAL, SOLUBLE AND INSOLUBLE DIETARY FIBRE

Analysis of dietary fibre was done using the enzymaticgravimetric method of AOAC 991.43. One g of defatted kenaf seeds were gelatinized with termamyl (heat stable alpha-amylase) at $100{ }^{\circ} \mathrm{C}$ for $1 \mathrm{~h}$ and then digested with protease $\left(60^{\circ} \mathrm{C}, 1 \mathrm{~h}\right)$, followed by incubation with amyloglucosidase $\left(60{ }^{\circ} \mathrm{C}, 1 \mathrm{~h}\right)$ to remove protein and starch. Insoluble dietary fibre (IDF) was filtered, and then remnants were washed with warm distilled water. Combined solution of filtrate and water washings were precipitated with 4 volumes of $95 \%$ ethanol (EtOH) for soluble dietary fibre (SDF) determination. Precipitate was then filtered and dried. Both SDF and IDF residues were corrected for protein, ash and blank, for the final calculation of SDF and IDF values. Total dietary fibre (TDF) was calculated by summation of SDF and IDF.

\section{PREPARATION OF DEFATTED KENAF SEED MEAL (DKSM) AND KENAF SEEDS DIETARY FIBRE (KSDF) THROUGH NON-ENZYMATIC HYDROLYSIS METHOD (KSDF (NEH))}

DKSM was prepared by removing oil contents whereas KSDF was prepared by removing both oil and protein contents from dried kenaf seeds that have been ground into powder, according to the method described by Chan et al. (2013) and Mariod et al. (2010), respectively, with slight modification. Fifty gram of pulverized kenaf seeds was weighed and put into $600 \mathrm{~mL}$ conical flask. $500 \mathrm{~mL}$ of food grade n-hexane was added into the conical flask and stirred for $1 \mathrm{~min}$. The kenaf seed-solvent suspension was ultra-sonicated for $1 \mathrm{~h}$. Then, the mixture was filtered through Whatman filter paper No. 1. The residue (DKSM) was re-extracted twice using the same procedure, collected and dried in an oven at $50{ }^{\circ} \mathrm{C}$ for $3 \mathrm{~h}$ to remove solvent residues. Then, DKSM was passed through a 0.5 $\mathrm{mm}$ sieve and kept in the chiller prior to protein removal for further extraction of dietary fibre. The protein content was removed by suspending dry defatted kenaf seed meal in distilled water at a 1:100 ratio. The mixture was stirred for $1 \mathrm{~h}$ at room temperature while adjusting the $\mathrm{pH}$ at 9.0. Then, it was centrifuged at $3500 \mathrm{rpm}$ for $15 \mathrm{~min}$ at room temperature. The supernatant was discarded and the pellet (KSDF) was collected in petri dish. KSDF was dried in an oven overnight at $50{ }^{\circ} \mathrm{C}$ and kept in $-20{ }^{\circ} \mathrm{C}$ for further analysis (Chan et al. 2013).

PREPARATION OF KENAF SEEDS DIETARY FIBRE THROUGH ENZYMATIC HYDROLYSIS METHOD (KSDF $(\mathrm{EH}))$

The extraction of total dietary fiber was prepared according to the method described by Daou and Zhang
(2012) with some modifications using Megazyme TDF kit. The defatted kenaf seeds were cooked with heatstable $\alpha$-amylase solution $(4 \mu \mathrm{L} / \mathrm{g})$ at $95-100^{\circ} \mathrm{C}$ for $1 \mathrm{~h}$ to give gelatinization, hydrolysis, and depolymerization of starch. After $\alpha$-amylase treatment, the sample was digested with protease solution $(10 \mu \mathrm{L} / \mathrm{g})$ at $60{ }^{\circ} \mathrm{C}$ for $1 \mathrm{~h}$ to solubilize and depolymerize proteins. Enzymatic treatment was completed with incubation with amyloglucosidase $(20 \mu \mathrm{L} / \mathrm{g})$ at $60^{\circ} \mathrm{C}$ for $1 \mathrm{~h}$ to hydrolyze starch fragments to glucose. After these treatments, the sample was suspended in four volumes of $80 \%$ ethanol (preheated at $60{ }^{\circ} \mathrm{C}$ ) to precipitate defatted KSDF and remove depolymerized protein and glucose. The precipitate was allowed to form at room temperature for $1 \mathrm{~h}$, and then centrifugation followed at $4000 \mathrm{rpm}$ for 15 min. The residue was filtered through Whatman filter paper No. 541 and washed twice with 78\% ethanol, 95\% ethanol and acetone in that order. Then, the residue was dried in a vacuum oven at $60^{\circ} \mathrm{C}$ after which, DKSDF were stored at $0-4{ }^{\circ} \mathrm{C}$ until further use (Daou \& Zhang 2012).

\section{TECHNO-FUNCTIONAL PROPERTIES OF KENAF SEEDS}

DIETARY FIBRE AND DEFATTED KENAF SEEDS MEAL

The water binding capacity (WBC) of the extracted fibre was determined using a method based on that of AACC (1983) which determined WBC of dietary fibre under external centrifugal force. Oil binding capacity (OBC) was measured using a method adapted from Lin et al. (1974). A four gram of sample was added to $20 \mathrm{~mL}$ of corn oil in a $50 \mathrm{~mL}$ centrifuge tube. The content was then stirred for $30 \mathrm{~s}$ every $5 \mathrm{~min}$ and, after $30 \mathrm{~min}$, the tubes were centrifuged at $1600 \times \mathrm{g}$ for $25 \mathrm{~min}$. The free oil was then decanted and the absorbed oil was then determined by difference. The oil binding capacity was expressed as absorbed oil per gram sample. The emulsifying capacity of dietary fibre was measured according to the method of Yasumatsu et al. (1972). Twenty millilitres of 7\% aqueous dispersion of the fibre was mixed with $20 \mathrm{~mL}$ of corn oil and blended in a Waring blender for $5 \mathrm{~min}$ at high speed. An aliquot was then centrifuged at $3000 \times \mathrm{g}$ for $5 \mathrm{~min}$. The percentage of total mixture that remained emulsified after centrifugation was expressed as stability index. The stability index of a good emulsion would be greater than $94 \%$, while that of a poor emulsion would only be 50\% (Wang \& Kinsella 1976; Yasumatsu et al. 1972). The viscosity of the dietary fibre was determined using the method by Frost et al. (1984). Four different concentrations of sample slurry, namely 1\%, 3\%, 5\% and $7 \%$, were prepared by slowly adding an appropriate amount of dietary fibre preparation to distilled water and mixing at high speed in a Waring blender for $1 \mathrm{~min}$. 
The solution was allowed to sit at room temperature for $24 \mathrm{~h}$ to come to equilibrium and for entrapped air to escape before viscosity measurements were made. The viscosity was measured using a calibrated Anton Paar Physica RheolabQC Model CC27/Q1, probe CC27 8630 at $1550.901 / \mathrm{s}$. The measurement was done at room temperature (Abdul-Hamid \& Luan 2000).

\section{PRODUCTION OF HIGH FIBRE PAN BREAD FORTIFIED WITH KENAF SEEDS DIETARY FIBRE}

Baking tests were carried out by adding $10 \%$ of dietary fibre; wheat bran fibre (WBF), rice bran fibre (RBF) and KSDF to bread formulations with commercial white bread as control. Breads were baked according to the standard method for commercial bread. A simple formulation is used to reduce additional effects of other ingredients consisting of wheat flour, water, dry yeast, salt, sugar, and shortening (Abdul-Hamid \& Luan 2000).

\section{MEASUREMENT OF BREAD SAMPLES VOLUME AND SPECIFIC VOLUME}

A laser volumeter (TexVol SVM-L500, Chopin, Paris, France) was used to measure the volume of bread loaves. The volume of the breads was measured after $2 \mathrm{~h}$ of baking. Each bread sample was placed on a rotating plateau $(60 \mathrm{rpm})$. A laser beam installed on a rotating arm was then used to measure the volume of the bread without contact. The accuracy of volume measurement using this equipment was estimated to be $\pm 0.4 \%$ according to 6 repetitions with the same bread. Each data point is the mean of 3 different breads. Specific volume (volume to mass ratio) was calculated (Rzigue et al. 2016).

\section{MEASUREMENT OF BREAD SAMPLES TEXTURE}

The firmness or texture of 1-day old, 2-day old and 3-day old bread was determined using a Model 5565 Instron Universal testing instrument. The texture was measured by adjusting the portion of the compression plunger until it barely touched the surface of the breads at the center of the slice. The plunger was then lowered at a constant speed until it compressed the breads to a predetermined degree (percentage of compression). The resulting peak force was measured in kilograms (Abdul-Hamid \& Luan 2000).

\section{DETERMINATION OF WATER ACTIVITY $\left(\mathrm{A}_{\mathrm{w}}\right)$ IN BREAD SAMPLES}

The water activity $\left(\mathrm{A}_{\mathrm{w}}\right)$ of bread samples was measured at $25^{\circ} \mathrm{C}\left( \pm 0.2^{\circ} \mathrm{C}\right)$ using an electronic dew-point water activity meter, Aqualab Series 3 model TE (Decagon Devices, Pullman, Washington, USA), equipped with a temperature-controlled system which ensure a temperature stable sampling environment. The equipment was calibrated with saturated salt solutions in the $A_{w}$ range of interest. For each determination, four or five replicates were obtained and the average reported. In order to speed up measurement time, bread samples in plastic sample holders were first equilibrated at $25^{\circ} \mathrm{C}$ by putting on an electronic chilling/heating plate (Decagon Devices, Model 40510, Pullman, Washington, USA).

\section{MEASUREMENT OF SURFACE COLOUR OF BREAD SAMPLES}

The surface colour of bread samples was determined by using Minolta Spectrophotometer CM-3600d (Japan). CIE colour values $\left(L^{*}, a^{*}, b^{*}\right)$ were used. The $L^{*}$ value indicates the lightness, $0-100$ representing dark to light. The $\mathrm{a}^{*}$ value gives the degree of the red-green colour, with a higher positive $\mathrm{a}^{*}$ value indicating more red. The $b^{*}$ value indicates the degree of the yellow-blue colour, with a higher positive $b^{*}$ value indicating more yellow.

\section{SENSORY EVALUATION OF BREAD SAMPLES}

Sensory analysis of the bread samples was conducted by 30 panelists, consisting of Faculty of Food Science and Technology staffs and students, using a 9-point hedonic scale for seven attributes (aroma, colour, porosity, deformability, softness, seedy flavor, and overall acceptability) where 9 is 'like extremely' and 1 is 'dislike extremely'. Four coded samples were served and water was provided for rinsing between samples (AbdulHamid \& Luan 2000).

\section{STATISTICAL ANALYSIS}

Data collected were analyzed using the Minitab 16 Software, Minitab Pty Ltd 2010 (Sydney, Australia). The significance of differences between control and treated samples was evaluated using Tukey's multiple range test at $5 \%$ level.

\section{RESULTS AND DISCUSSION}

\section{NUTRITIONAL COMPOSITION OF KENAF SEEDS}

The nutritional composition of kenaf seeds variety V36 was reported in Table 1. As shown, kenaf seeds are a great source of dietary fibre $(28.87 \mathrm{~g} / 100 \mathrm{~g})$, protein $(27.07$ $\mathrm{g} / 100 \mathrm{~g})$, oil (23.78 g/100 g) and mineral (5.55 g/100 g). 
In comparison to the previous findings by Nyam et al. (2009) that used the same variety (V36), this study showed higher amounts of protein, oil and fibre. This study finding also in contrast with Mariod et al. (2010) that used the same variety (V36). They reported on high protein content $(29.8 \%)$ but fibre and oil content were lower with $11.5 \%$ and $22.6 \%$, respectively. The difference might be due to the different harvesting year and conditions of the seeds during harvesting, post harvesting and storage conditions. The high amount of protein in kenaf seed indicate that it can also be used as an alternative source of dietary protein. Kenaf seeds also consists of high amount of oil with $23.78 \mathrm{~g} / 100 \mathrm{~g}$ which is slightly higher than kenaf seed oil reported by Mariod et al. (2010) and Nyam et al. (2009) and recently, kenaf seed oil has been commercialized as a nutraceutical oil because of the high antioxidant content in the oil. The by-product from this new industry which is defatted kenaf seeds also has high dietary fibre content. This means that it can be use as source of dietary fibre and a functional food ingredient.

\section{TECHNO-FUNCTIONAL PROPERTIES OF DEFATTED} KENAF SEEDS MEAL (DKSM) AND KENAF SEEDS DIETARY FIBRE (KSDF)

Table 2 reported the results of the water-binding capacity (WBC) of defatted kenaf seeds meal (DKSM) and dietary fibre were produced from defatted kenaf seeds through enzymatic hydrolysis $(\mathrm{KSDF}(\mathrm{EH}))$ and non-enzymatic hydrolysis $(\mathrm{KSDF}(\mathrm{NEH}))$, respectively. The $\mathrm{WBC}$ of $\operatorname{KSDF}(\mathrm{EH})$ was significantly $(\mathrm{p}<0.05)$ higher than KSDF (NEH) and DKSM. KSDF (EH) showed the highest WBC $(3.55 \pm 0.04 \mathrm{~g}$ of water/g of sample) followed by KSDF (NEH) $(3.06 \pm 0.02 \mathrm{~g}$ of water/g of sample) and DKSM (2.07 $\pm 0.05 \mathrm{~g}$ of water/g of sample). Water binding capacity (WBC) or water holding properties is the ability to absorb water and hold even after receive external forces (Laufenberg \& Schulze 2009). However, this study showed lower water holding capacity than those reported on pea pod (PP) fibre and broad bean pod (BBP) which contain 4.64 and $6.98 \mathrm{~g}$ water/g dry sample, respectively (Belghith Fendri et al. 2016). WBC can be increased with the increase of the water soluble fibres (Tan et al. 2017). The low water soluble fibres of kenaf seed $(2.87 \mathrm{~g} / 100 \mathrm{~g})$ might be the one of the reason on low WBC in this study.

The KSDF $(E H)$ shows significantly $(\mathrm{p}<0.05)$ higher OBC than DKSM and KSDF (NEH) with $1.28 \pm 0.01,1.04$ \pm 0.05 and $0.89 \pm 0.02 \mathrm{~g}$ of oil $/ \mathrm{g}$ of sample, respectively, as reported in Table 2. However, these values were lower as compared than those who reported on pea pod ( $p p)$ fibre and broad bean pod (BBP) fibre that have $2.86 \mathrm{~g}$ oil/ dry sample and $3.39 \mathrm{~g}$ oil/dry sample (Belghith Fendri et al. 2016).

The emulsifying capacity (EC) is meant as the ability of protein solution or suspension to emulsify with oil (Zayas 1997). Despite the low protein content, the EC of DKSM, KSDF (EH) and KSDF (NEH) were 27.16\%, $40.53 \%$ and $43.67 \%$, respectively. The dietary fibre has been reported to have an emulsifying activity and emulsifying stability properties (Xie et al. 2017). In the past few years, the addition of dietary fibre in food products has been practice as it give good functional properties such as emulsifying stability (Huber et al. 2016; Park et al. 2020). The EC of KSDF might be contributed by the Pickering emulsion (Yang et al. 2017) where the solid particles was used to stabilize the emulsion (Chen et al. 2020). The solid particle will accumulate at the interface of the two immiscible liquids and stabilize the droplets against coalescence (Yang et al. 2017). The solid particles for Pickering emulsions can be used from food grade organic materials such as polysaccharides particles, protein particles and lipid particles, however, the stability of Pickering emulsion is lower when food grade materials is used (Chen et al. 2020). Some protein are used to prepare and stabilize the Pickering emulsions due to their amphiphilic properties and strong surface activity (Guo 2021). The EC of KSDF (EH) and KSDF (NEH) might be contributed by the soluble and insoluble polysaccharide as well as protein that help in stabilize the Pickering emulsion.

Figure 1 shows the viscosity of KSDF (EH), KSDF (NEH) and DKSM at different concentrations. KSDF $(\mathrm{EH})$ presented significantly $(\mathrm{p}<0.05)$ higher viscosity than KSDF (NEH) and DKSM. However, all samples exhibited low viscosity. This might due to KSDF and DKSM contain lower amount of soluble fibre and watersoluble fibre which were only $3 \%$. The viscosity of solution can be increased by the water soluble fibres (Daou \& Zhang 2014).

\section{HIGH FIBRE PAN BREAD FORTIFIED WITH KSDF}

Bread, which is a very popular staple food made from flour, is one of the oldest functional foods believed to have existed since the Neolithic era (Kourkouta et al. 2017 ) is considered as a main source of the dietary fibre. However, the amount of dietary fibre in normal bread is still inadequate to fulfill total dietary fibre intake suggested by the Malaysian Recommended Nutrient 
Intakes (RNI) which is 20 to $30 \mathrm{~g}$ daily for all age groups in order to prevent diet-related chronic diseases (National Coordinating Committee on Food and Nutrition 2017). Thus, functional and nutritional values, i.e. antioxidant capacity, macronutrient, micronutrient, calorie, and dietary fibre contents of this food product can be enhanced by adding alternative dietary fibre sources to substitute the wheat flour completely or partially (Yangilar 2013).

Table 3 shows the results of analysis on the physical properties of the bread samples. The weight of white bread (control) was $392.0 \mathrm{~g}$. Addition of dietary fibres namely wheat bran fibre, rice bran fibre and KSDF significantly $(p<0.05)$ decreased the weight of the breads to 388.0 $\mathrm{g}, 387.0 \mathrm{~g}$ and $389.0 \mathrm{~g}$, respectively. Proofing time of KSDF bread was significantly $(\mathrm{p}<0.05)$ higher than that of white bread. The difference in the weights between the three dietary fibre-fortified breads were insignificant $(p>0.05)$. The addition of dietary fibres in bread increase its functional properties, however, there are also unfavourable effects towards the physical characteristics of the bread like volume reduction and different in texture (Gómez et al. 2003). The height, volume and specific volume of bread decreased significantly $(\mathrm{p}<0.05)$, and the smallest height, volume and specific volume were exhibited by KSDF bread. According to the study by Rubel et al. (2015), the addition of inulin rich-carbohydrate (IRC) in bread decrease the bread volume. This effects might be caused by the gluten diluting effect where the gas retention with no increment in gas production that lead to structure destruction (Dhingra et al. 2012; Mandala et al. 2009; Morris \& Morris 2012; Nwosu et al. 2014). Therefore, the reduction of height, volume and specific volume in this study were due to the addition of KSDF.

The parameters for shelf-life properties of the bread samples were water activity $\left(\mathrm{A}_{\mathrm{w}}\right)$, moisture, texture, and colour. The quality of baked products can be determined on the water activity $\left(\mathrm{A}_{\mathrm{w}}\right)$, texture, and surface colour. These attributes will determine shelf-life, quality, and acceptability of food products. Changes in the parameters were observed for a duration of 3 days. The results are as presented in Table 4.

The water activity of white bread significantly ( $p$ $<0.05$ ) remained at the highest during the 3 days of storage period due to lack of dietary fibre in the bread formulation. The addition of dietary fibres significantly $(\mathrm{p}<0.05)$ decreased the water activity of the breads. However, the water activity values of WBF bread (0.8723), RBF bread (0.8473), and KSDF bread (0.8463) after baking are considered high for baked products. The differences in water activity values between all three dietary fibre-fortified breads during the 3 day-storage were insignificant $(\mathrm{p}>0.05)$.

The moisture content of dietary-fibre fortified breads was significantly $(p<0.05)$ lower than white bread after the baking process. However, on day 2 and 3, the moisture content of white bread decreased, that caused dietary-fibre fortified breads to have significantly $(\mathrm{p}<0.05)$ higher moisture content. Despite that, the changes in moisture contents of all dietary-fibre fortified breads from day 1 to day 3 were insignificant $(\mathrm{p}>0.05)$.

The addition of dietary fibre into the bread formulation causing the force required to compress the bread decreased significantly $(p<0.05)$. The firmness of the breads was found to be significantly $(\mathrm{p}<0.05)$ lowest with KSDF addition throughout the 3 days of storage. Additionally, with increased storage time, all bread formulations increased in firmness. This is because more cross links are formed between starch and protein network in the breads and make the existing linkages even stronger (Martin \& Hosney 1991). Dietary fibres play a significant role to extend shelf-life of foods. Since KSDF has a better WBC than wheat bran and rice bran as mentioned earlier, choosing KSDF as a source of dietary fibre in bread making might be more beneficial because of its capacity to retain more water (Yangilar 2013).

The determination of colour parameters of the surfaces of bread samples was shown in Table 5. Surface colour of the breads had a significant effect after the addition of dietary fibres. Bread formulations that were added with dietary fibres were significantly $(\mathrm{p}<0.05)$ darker (lower L-values) than the white bread, with KSDF significantly $(\mathrm{p}<0.05)$ having the lowest L-value during the 3 days of storage. Higher L-value indicates increase in whiteness of the bread surface (Majzoobi et al. 2011). Besides that, the dietary-fibre fortified bread has the $a^{*}$ and $b^{*}$ values significantly $(p<0.05)$ higher than the white bread. After baking, KSDF bread had a significantly $(\mathrm{p}<0.05)$ lower $\mathrm{a}^{*}$ value (lesser redness) than WBF but after 3 days of storage, KSDF bread increased in $\mathrm{a}^{*}$ value that is similar to that of WBF bread. For yellowness, KSDF bread had significantly $(\mathrm{p}<0.05)$ lower $b^{*}$ value (lesser yellowness) when compared to both WBF bread and RBF bread.

Zanoni et al. (1995) mentioned that surface colour is a critical index to measure on baked products because it is one of the most important sensory parameters that influence consumers to buy baked products. During baking, Maillard and caramelization reactions occurred as 
a result of decrease in water content which give colour to the bread surfaces (Jaeger et al. 2010). The surface colour also refers to surface 'browning'. Angioloni and Collar (2012) described that the presence of dietary fibres in bread formulations could affect the colour characteristics of the breads. Raidi and Klein (1983) also mentioned that there are changes on the surface colour of bread from creamy white to dull brown or dark when the non-wheat flour is presence in the bread dough. The decrease in lightness of the breads fortified with dietary fibres could be the result of water binding to the fibres, which aids chemical reactions between reducing sugars and amino acids (Feili 2013).

\section{SENSORY ANALYSIS}

A spider web diagram of the means of sensory evaluation scores that show the degree of liking for four different bread formulations is shown in Figure 2. KSDF bread was shown having the nicest aroma as compared to commercial white bread, WBF bread, and RBF bread. The appearance of bread is characterized by colour and porosity. Although the scores are almost similar, in terms of colour, KSDF shows the highest score (5.86) as compared to WBF bread (5.44), and RBF bread (5.06) which were formulated using other sources of dietary fibre. The highest score for colour was obtained by white bread (7.61). The porosity of KSDF bread (5.69) was in between that of WBF bread (5.03) and RBF (6.04) bread. Thus, appearance-wise, KSDF bread is the second best. Deformability and softness represent the textural characteristics of the breads. The deformability of KSDF bread had a little higher mean score (7.50) than RBF bread (7.30). KSDF bread had the highest mean score (8.36) for softness, followed by white bread (7.54), rice bran fibre bread (6.41), and wheat bran fibre read (6.03). The scores for seedy flavor showed that white bread (7.27) and KSDF (7.47) are nearly equal. Nevertheless, the overall acceptability evaluation showed that KSDF bread was the most preferred type of bread amongst other breads with an overall score of 7.18. The addition of KSDF into bread formulation has increased the aroma and softness of the bread that contributed to a better consumers' acceptance.

TABLE 1. Proximate analysis of kenaf seeds (variety V36)

\begin{tabular}{lc}
\hline Component & Nutritional content (g/100 g kenaf seeds) \\
\hline Moisture & $4.74 \pm 0.08$ \\
Ash & $5.55 \pm 0.04$ \\
Crude protein ${ }^{\text {a }}$ & $27.07 \pm 0.47$ \\
Crude fat & $23.78 \pm 1.35$ \\
Total dietary fibre $^{\text {b }}$ & $28.87 \pm 2.43$ \\
$\quad$ Insoluble dietary fibre & $26.00 \pm 2.94$ \\
$\quad$ Soluble dietary fibre & $2.87 \pm 0.51$ \\
Digestible carbohydrate & \\
\end{tabular}

Value are expressed as means \pm standard deviation

a Crude protein $=\mathrm{N}(\%) \times 6.25, \mathrm{~b}$ Total dietary fibre $=$ Insoluble dietary fibre + Soluble dietary fibre,

c Digestible Carbohydrate $=100-\sum$ (moisture + ash + protein + fat + total dietary fibre $)$ 
TABLE 2. Comparison of water binding capacity, oil binding capacity and emulsifying capacity of three different treatments of kenaf seeds ${ }^{\mathrm{a}}$

\begin{tabular}{lccc}
\hline Samples & $\begin{array}{c}\text { Water binding } \\
\text { capacity }(\mathrm{g} / \mathrm{g})^{\mathrm{b}}\end{array}$ & $\begin{array}{c}\text { Oil binding capacity } \\
(\mathrm{g} / \mathrm{g})^{\mathrm{b}}\end{array}$ & $\begin{array}{c}\text { Emulsifying capacity } \\
(\%)\end{array}$ \\
\hline DKSM & $2.07^{\mathrm{a}} \pm 0.05$ & $1.04^{\mathrm{a}} \pm 0.05$ & $27.16^{\mathrm{a}} \pm 12.74$ \\
$\mathrm{KSDF}(\mathrm{EH})$ & $3.55^{\mathrm{b}} \pm 0.04$ & $1.28^{\mathrm{b}} \pm 0.01$ & $40.53^{\mathrm{a}} \pm 3.87$ \\
$\mathrm{KSDF}(\mathrm{NEH})^{\mathrm{c}}$ & $3.06^{\mathrm{c}} \pm 0.02$ & $0.89^{\mathrm{c}} \pm 0.02$ & $43.67^{\mathrm{a}} \pm 4.96$ \\
\hline
\end{tabular}

Values are means \pm standard deviation of triplicate readings. Means within a column bearing the different letters are significantly different at $5 \%$ level as determined by the Tukey's multiple range test DKSM - Defatted Kenaf Seeds Meal, KSDF (EH) - Enzymatic Hydrolyzed Kenaf Seeds Dietary Fibre, KSDF (NEH) - Non-Enzymatic Hydrolyzed Kenaf Seeds Dietary Fibre

TABLE 3. Physical properties of high fibre bread fortified with WBF, RBF, and KSDF

\begin{tabular}{lcccc}
\hline Parameters & White bread & WBF bread & RBF bread & $\begin{array}{c}\text { KSDF } \\
\text { bread }\end{array}$ \\
\hline Weight $(\mathrm{g})$ & $392.00^{\mathrm{a}}$ & $388.00^{\mathrm{b}}$ & $387.00^{\mathrm{b}}$ & $389.00^{\mathrm{a}, \mathrm{b}}$ \\
Proofing time (s) & $101.33^{\mathrm{b}}$ & $129.33^{\mathrm{a}}$ & $107.00^{\mathrm{b}}$ & $132.33^{\mathrm{a}}$ \\
Height $(\mathrm{cm})$ & $16.46^{\mathrm{a}}$ & $15.27^{\mathrm{b}}$ & $14.40^{\mathrm{c}}$ & $14.13^{\mathrm{c}}$ \\
Volume $\left(\mathrm{cm}^{3}\right)$ & $2442.47^{\mathrm{a}}$ & $2324.30^{\mathrm{b}}$ & $2202.13^{\mathrm{c}}$ & $2200.70^{\mathrm{c}}$ \\
Specific volume $\left(\mathrm{cm}^{3} / \mathrm{g}\right)$ & $6.23^{\mathrm{a}}$ & $5.98^{\mathrm{b}}$ & $5.69^{\mathrm{c}}$ & $5.653^{\mathrm{c}}$ \\
\hline
\end{tabular}

Values are means of triplicate readings. Means within a column bearing the different letters are significantly different at $5 \%$ level as determined by the Tukey's multiple range test

TABLE 4. Shelf-life properties of high fibre bread fortified with WBF, RBF and KSDF

\begin{tabular}{lccccc}
\hline Parameters & Day & White bread & WBF bread & RBF bread & KSDF bread \\
\hline Water activity $\left(\mathrm{A}_{\mathrm{w}}\right)$ & 1 & $0.9116^{\mathrm{a}}$ & $0.8723^{\mathrm{b}}$ & $0.8473^{\mathrm{c}}$ & $0.8643^{\mathrm{b}}$ \\
& 2 & $0.8853^{\mathrm{a}}$ & $0.7933^{\mathrm{c}}$ & $0.8233^{\mathrm{b}}$ & $0.8220^{\mathrm{b}}$ \\
& 3 & $0.9040^{\mathrm{a}}$ & $0.8773^{\mathrm{b}}$ & $0.8596^{\mathrm{b}}$ & $0.8557^{\mathrm{b}}$ \\
Moisture & 1 & $39.3^{\mathrm{a}}$ & $35.0^{\mathrm{b}}$ & $31.4^{\mathrm{d}}$ & $34.2^{\mathrm{c}}$ \\
& 2 & $29.4^{\mathrm{d}}$ & $35.6^{\mathrm{a}}$ & $31.8^{\mathrm{c}}$ & $33.5^{\mathrm{b}}$ \\
& 3 & $29.5^{\mathrm{d}}$ & $34.3^{\mathrm{a}}$ & $31.7^{\mathrm{c}}$ & $33.2^{\mathrm{b}}$ \\
Texture $(\mathrm{kg})$ & 1 & $94.15^{\mathrm{a}}$ & $74.00^{\mathrm{b}}$ & $97.27^{\mathrm{a}}$ & $54.15^{\mathrm{c}}$ \\
& 2 & $126.78^{\mathrm{a}}$ & $85.29^{\mathrm{c}}$ & $105.04^{\mathrm{b}}$ & $68.27^{\mathrm{d}}$ \\
& 3 & $144.17^{\mathrm{b}}$ & $137.44^{\mathrm{c}}$ & $161.22^{\mathrm{a}}$ & $80.50^{\mathrm{d}}$ \\
\hline
\end{tabular}

Values are means of triplicate readings. Means within a column bearing the different letters are significantly different at $5 \%$ level as determined by the Tukey's multiple range test 
TABLE 5. Colour parameters of the surfaces of bread samples

\begin{tabular}{|c|c|c|c|c|c|}
\hline Parameters & Day & White bread & WBF bread & RBF bread & KSDF bread \\
\hline \multirow[t]{3}{*}{$\mathrm{L}$} & 1 & $71.22^{\mathrm{a}}$ & $66.39^{\mathrm{b}}$ & $65.12^{b}$ & $59.06^{\mathrm{c}}$ \\
\hline & 2 & $73.86^{\mathrm{a}}$ & $63.42^{b, c}$ & $67.39^{b}$ & $58.91^{\mathrm{c}}$ \\
\hline & 3 & $76.04^{a}$ & $66.80^{b}$ & $65.68^{b}$ & $57.28^{\mathrm{c}}$ \\
\hline \multirow[t]{3}{*}{$\mathrm{a}$} & 1 & $-0.67^{a}$ & $1.13^{\mathrm{b}}$ & $-0.30^{b}$ & $0.80^{\mathrm{a}}$ \\
\hline & 2 & $-0.71^{d}$ & $1.41^{\mathrm{a}}$ & $-0.11^{c}$ & $0.74^{b}$ \\
\hline & 3 & $-0.82^{c}$ & $1.24^{\mathrm{a}}$ & $0.10^{b}$ & $1.24^{\mathrm{a}}$ \\
\hline \multirow[t]{3}{*}{$\mathrm{b}$} & 1 & $6.01^{\mathrm{c}}$ & $11.37^{\mathrm{a}}$ & $11.97^{\mathrm{a}}$ & $9.84^{b}$ \\
\hline & 2 & $5.91^{\mathrm{c}}$ & $12.15^{\mathrm{a}}$ & $12.14^{\mathrm{a}}$ & $9.22^{b}$ \\
\hline & 3 & $6.51^{\mathrm{c}}$ & $11.85^{\mathrm{a}}$ & $11.87^{\mathrm{a}}$ & $10.07^{b}$ \\
\hline
\end{tabular}

Values are means of triplicate readings. Means within a column bearing the different letters are significantly different at $5 \%$ level as determined by the Tukey's multiple range test

Viscosity of Kenaf Seeds Dietary Fibre vs Solution concentration

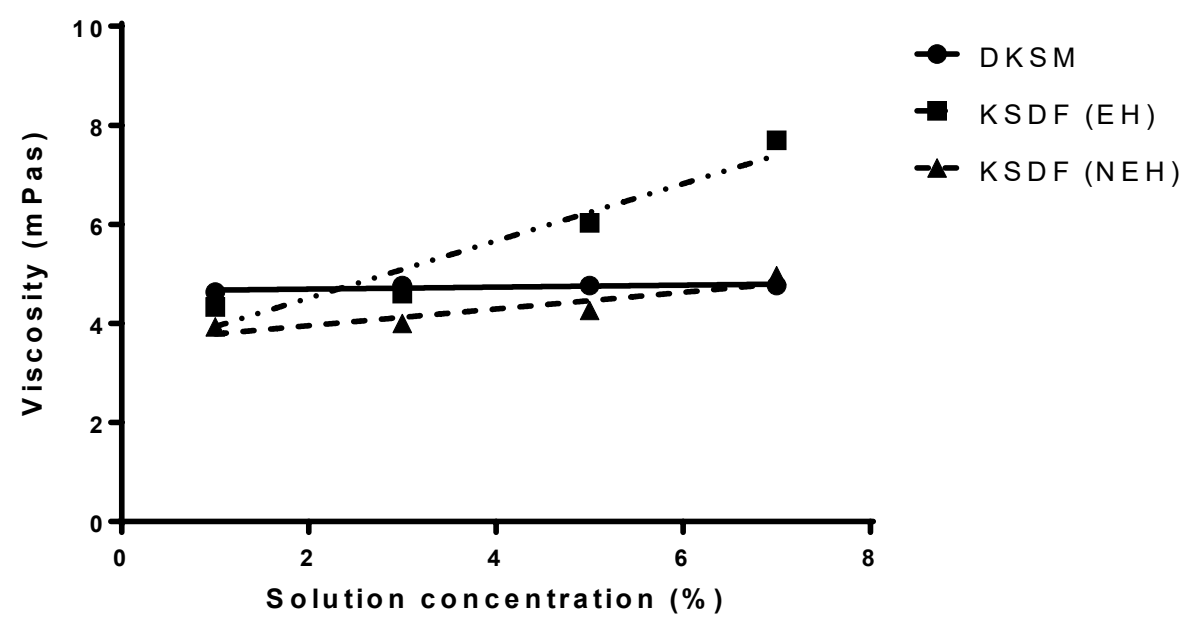

FIGURE 1. Viscosity of dietary fibres from defatted kenaf seeds (KSDF) and defatted kenaf seeds meal (DKSM) 


\section{Degree of Liking of Diferent Breads}

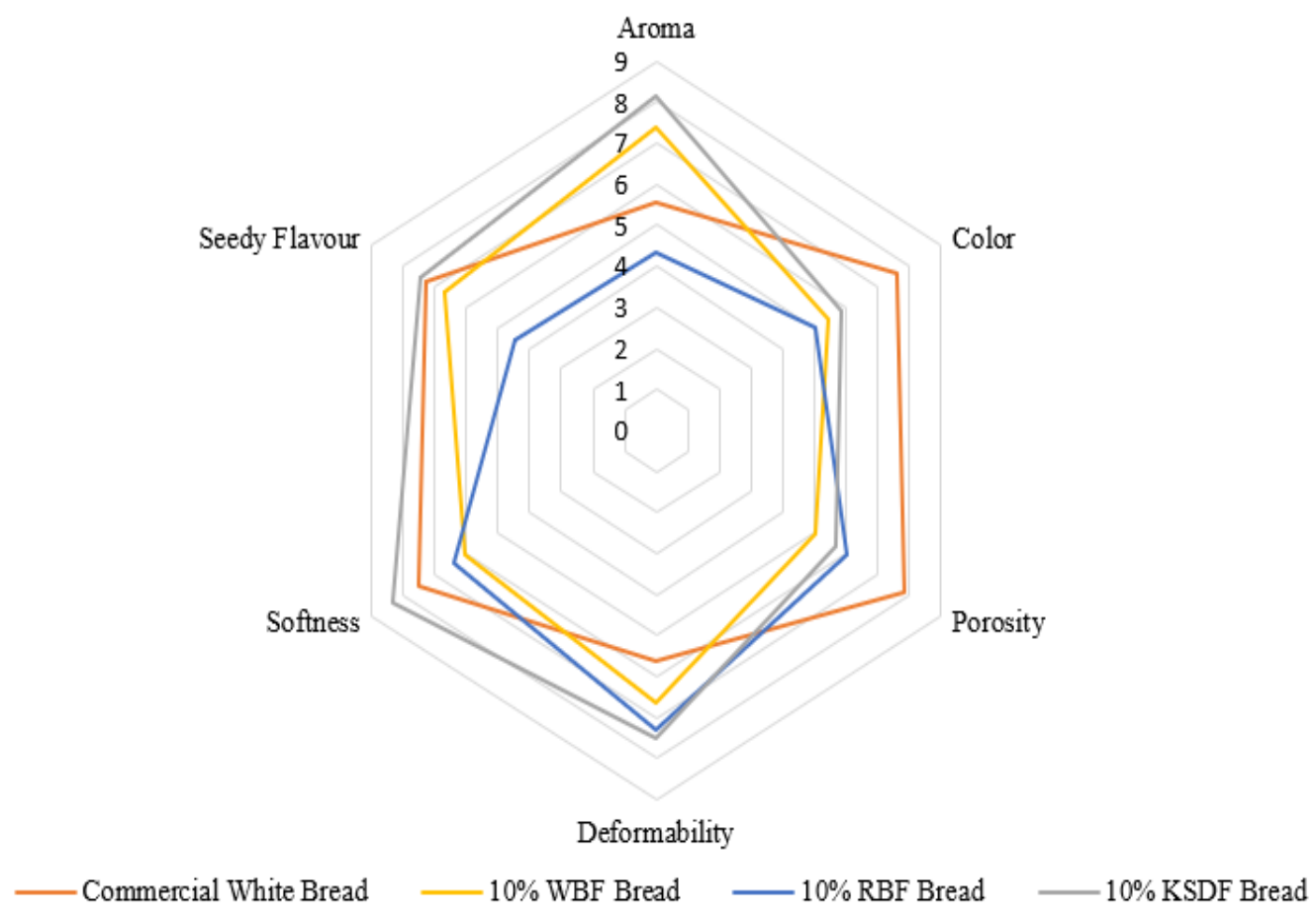

FIGURE 2. Spider web diagram of the means of sensory evaluation scores. Each spoke of the diagram represents an individual sensory attribute. The degrees of liking scores go from lower values at the center point to higher values at the outer end of the spoke

\section{CONCLUSION}

This study showed that kenaf seeds of variety V36 have high nutritional content. The highest nutritional component in the kenaf seeds is dietary fibre. This agricultural byproduct can be fully utilized through the preparation of kenaf seeds dietary fibre (KSDF). KSDF can be used in development of functional foods due to the great potential in food applications. Furthermore, KSDF could play an important role in making a better quality of food products due to its good functional properties. In this study, KSDF was used in the formulation of high fibre bread. The results of the present work showed that the quality of KSDF bread is comparable to that of WBF and RBF breads. It was also found that bread which has been fortified with $10 \%$ KSDF was the most acceptable by the panelists based on the seven attributes.

\section{ACKNOWLEDGEMENTS}

The authors wish to thank the National Kenaf and Tobacco Board, Malaysia for providing kenaf seeds.
We are also thankful to the laboratory staffs of FSTM, Universiti Putra Malaysia for providing equipment and materials needed for this study. This work was supported by the National Kenaf and Tobacco Board, Malaysia and Faculty of Food Science and Technology (FSTM), Universiti Putra Malaysia. The authors declare no conflict of interest.

\section{REFERENCES}

Abdul-Hamid, A. \& Luan, Y.S. 2000. Functional properties of dietary fibre prepared from defatted rice bran. Food Chem. 68(1): 15-19.

Angioloni, A. \& Collar, C. 2012. High legume-wheat matrices: An alternative to promote bread nutritional value meeting dough viscoelastic restrictions. European Food Research and Technology 234: 273-284.

Ayadi, R., Hanana, M., Mzid, R., Hamrouni, L., Khouja, M.L. \& Salhi Hanachi, A. 2017. Hibiscus cannabinus L. - Kenaf: A review paper. Journal of Natural Fibers 14(4): 466-484.

Beyer, K.M.M. 2016. Chapter 10: Chronic Environmental Diseases: Burdens, Causes, and Response. In Biological and Environmental. 
Belghith Fendri, L., Chaari, F., Maaloul, M., Kallel, F., Abdelkafi, L., Ellouz Chaabouni, S. \& Ghribi-Aydi, D. 2016. Wheat bread enrichment by pea and broad bean pods fibers: Effect on dough rheology and bread quality. LWT - Food Science and Technology 73: 584-591.

Chan, K.W., Khong, N.M.H., Iqbal, S., Mansor, S.M. \& Ismail, M. 2013. Defatted kenaf seed meal (DKSM): Prospective edible flour from agricultural waste with high antioxidant activity. LWT - Food Sci. Technol. 53(1): 308-313.

Chen, L., Ao, F., Ge, X. \& Shen, W. 2020. Food-grade pickering emulsions: Preparation, stabilization and applications. Molecules 25(14): 1-24.

Cheng, Z., Bao, R.L., Sameshima, K., Fu, D.X. \& Chen, J.K. 2004. Identification and genetic relationship of kenaf germplasm revealed by AFLP analysis. Genet Resour. Crop Evol. 51: 393-401

Dahl, W.J. \& Stewart, M.L. 2015. Position of the Academy of Nutrition and Dietetics: Health implications of dietary fiber. Journal of the Academy of Nutrition and Dietetics 115(11): 1861-1870.

Dao, C. \& Zhang, H. 2012. Study on functional properties of physically modified dietary fibres derived from defatted rice bran. J. Agric. Sci. 4(9): 85-97.

Daou, C. \& Zhang, H. 2014. Functional and physiological properties of total, soluble, and insoluble dietary fibres derived from defatted rice bran. Journal of Food Science and Technology 51(12): 3878-3885.

Dempsey, J.M. 1975. Kenaf. Fiber Crops. University of Florida Press. Tallahassee, FL: Rose Printing Company.

Dhingra, D., Michael, M., Rajput, H. \& Patil, R.T. 2012. Dietary fibre in foods: A review. Journal of Food Science and Technology 49(3): 255-266.

Feili, R. 2013. Physical and sensory analysis of high dietary fiber bread incorporated with jackfruit rind flour. Food Sci. Tech. 1: 30-36.

Frost, J., Hegedus, E.F. \& Glicksman, M. 1984. Objective characterization of hydrocolloid organoleptic properties. Food Tech. 38(1): 118-122.

Ghafar, S.A.A., Ismail, M., Yazan, L.S., Fakurazi, S., Ismail, N., Chan, K.W. \& Tahir, P.M. 2013. Cytotoxic activity of kenaf seed oils from supercritical carbon dioxide fluid extraction towards human colorectal cancer (HT29) cell lines. Evid. Based Complement Alternat. Med. 2013: Article ID. 549705.

Gómez, M., Ronda, F., Blanco, C.A., Caballero, P.A. \& Apesteguía, A. 2003. Effect of dietary fibre on dough rheology and bread quality. European Food Research and Technology 216: 51-56.

Guo, Q. 2021. Progress in the preparation, stability and functional applications of pickering emulsion. IOP Conference Series: Earth and Environmental Science 639: 1-8.

Huber, E., Francio, D.L., Biasi, V., Mezzomo, N. \& Ferreira, S.R.S. 2016. Characterization of vegetable fiber and its use in chicken burger formulation. Journal of Food Science and Technology 53(7): 3043-3052.
Jaeger, H., Janositz, A. \& Knorr, D. 2010. The Maillard reaction and its control during food processing. The potential of emerging technologies. Pathol. Biol. 58(3): 207-213.

Kendall, C.W.C., Esfahani, A. \& Jenkins, D.J.A. 2010. The link between dietary fibre and human health. Food Hydrocoll. 24(1): 42-48.

Kourkouta, L., Koukourikos, K., Iliadis, C., Ouzounakis, P., Monios, A. \& Tsaloglidou, A. 2017. Bread and health. J. Pharm. Pharmacol. 5: 821-826.

Laufenberg, G. \& Schulze, N. 2009. A Modular Strategy for Processing of Fruit and Vegetable Wastes into Value-Added Products. Handbook of Waste Management and CoProduct Recovery in Food Processing. (Vol. 2). Cambridge: Woodhead Publishing Limited.

Lin, M.J.Y., Humbert, E.S. \& Sosulski, F. 1974. Certain functional properties of sunflower meal products. Journal of Food Science 39(2): 368-370.

Majzoobi, M., Ghavi, F.S., Farhanaky, A., Jamalian, J. \& Mesbahi, G. 2011. Effect of tomato pomace powder on the physicochemical properties of flat bread (Barbari bread). Journal of Food Processing and Preservation 35(2): 247256.

Mandala, I., Polaki, A. \& Yanniotis, S. 2009. Influence of frozen storage on bread enriched with different ingredients. Journal of Food Engineering 92(2): 137-145.

Mariod, A.A., Fathy, S.F. \& Ismail, M. 2010. Preparation and characterisation of protein concentrates from defatted kenaf seed. Food Chem. 123(3): 747-752.

Martin, M.L. \& Hosney, R.C.A. 1991. A mechanism of bread firming II. Role of starch hydrolyzing enzymes. Cereal Chem. 68: 503-507.

Mat Daham Mohd Daud, Masnira Mohammad Yusoff, Noor Syahira Nasarudin, Zainal Abidin Hassan, Nik Ab Lah N Mohamed, Wong Choi Chee, Mohd Najib Mohd Amin \& Abdullah Othman. 2015. Manual Teknologi Pengeluaran Kenaf di Malaysia. Edisi ketiga. Serdang: Institut Penyelidikan dan Kemajuan Pertanian Malaysia (MARDI).

Mohamed, A., Bhardwaj, H., Hamama, A. \& Webber, C. 1995. Chemical composition of kenaf (Hibiscus cannabinus L.) seed oil. Ind. Crops Prod. 4: 157-165.

Morris, C. \& Morris, G.A. 2012. The effect of inulin and fructo-oligosaccharide supplementation on the textural, rheological and sensory properties of bread and their role in weight management: A review. Food Chemistry 133(2): 237-248.

National Coordinating Committee on Food and Nutrition, (NCCFN). 2017. Recommended Nutrient Intakes for Malaysia. A Report of the Technical Working Group on Nutritional Guidelines. Putrajaya: Ministry of Health Malaysia.

Nwosu, U.L., Elochukwu, C.U. \& Onwurah, C.O. 2014. Physical characteristics and sensory quality of bread produced from wheat/African oil bean flour blends. African Journal of Food Science 8(6): 351-355. 
Nyam, K.L., Tan, C.P., Lai, O.M., Long, K. \& Man, Y.B.C. 2009. Properties and bioactive compounds of selected seed oils. LWT - Food Sci. Technol. 42(8): 1396-1403.

Olawepo, K.D., Banjo, O.T., Jimoh, W.A., Fawole, W.O., Orisasona, O. \& Ojo-Daniel, A.H. 2014. Effect of cooking and roasting on nutritional and anti-nutritional factors in kenaf (Hibiscus cannabinus L.) seed meal. Food Sci. Qual. Manag. 24: 1-5.

Park, S.Y., Oh, T.S., Kim, G.W. \& Kim, H.Y. 2020. Quality properties of various dietary fibers as isolated soy protein (ISP) replacements in pork emulsion systems. Journal of Animal Science and Technology 62(1): 94-102.

Raidi, M.A. \& Klein, B.P. 1983. Effect of soy or field pea flour substitution on physical and sensory characteristics of chemically leavened quick breads. Cereal Chem. 60: 367-370.

Rubel, I.A., Pérez, E.E., Manrique, G.D. \& Genovese, D.B. 2015. Fibre enrichment of wheat bread with Jerusalem artichoke inulin: Effect on dough rheology and bread quality. Food Structure 3: 21-29.

Rzigue, A., Monteau, J-Y., Marmi, K., Le Bail, A., Chevallier, S., Réguerre, A-L. \& Jury, V. 2016. Bread collapse. Causes of the technological defect and impact of depanning time on bread quality. Journal of Food Engineering 182: 72-80.

Saba, N., Paridah, M.T., Jawaid, M., Abdan, K. \& Ibrahim, N.A. 2015. Potential utilization of kenaf biomass in different applications. In Agricultural Biomass Based Potential Materials, edited by Hakeem, K., Jawaid, M. \& Y. Alothman O. Switzerland: Springer-Verlag. pp. 1-34.

Tan, C., Wei, H., Zhao, X., Xu, C. \& Peng, J. 2017. Effects of dietary fibers with high water-binding capacity and swelling capacity on gastrointestinal functions, food intake and body weight in male rats. Food and Nutrition Research 61(1): $1-8$.

Timm, D. \& Slavin, J.L. 2008. Dietary fiber and the relationship to chronic diseases. Am. J. Lifestyle Med. 2(3): 233-240.

Wang, J.C. \& Kinsella, J.E. 1976. Functional properties of alfalfa leaf protein: Foaming. Journal of Food Science 41(3): 498-501.

World Health Organization. 2020. Cancer Today. https://gco.iarc. fr/today/home. Accessed on June 29, 2020.

World Health Organization. 2017. Cardiovascular Diseases (CVDs). https://www.who.int/news-room/fact-sheets/detail/ cardiovascular-diseases-(cvds).

Xie, F., Zhang, W., Lan, X., Gong, S., Wu, J. \& Wang, Z. 2017. Physicochemical properties and structural characteristics of soluble dietary fibers from yellow and purple fleshed potatoes by-product. International Journal of Food Properties 20(Issue Sup. 3): S2939-S2949.
Yang, Y., Fang, Z., Chen, X., Zhang, W., Xie, Y., Chen, Y., Liu, Z. \& Yuan, W. 2017. An overview of pickering emulsions: Solid-particle materials, classification, morphology, and applications. Frontiers in Pharmacology 8(287): 1-20.

Yangilar, F. 2013. The application of dietary fibre in food industry: Structural features, effects on health and definition, obtaining and analysis of dietary fibre: A review. J. Food Nutr. Res. 1: 13-23.

Yasumatsu, K., Sawada, K., Moritaka, S., Mikasi, M., Toda, T. \& Tshi, K. 1972. Whipping and emulsifying properties of soybean products. Agricultural Biochemistry 36: 719- 727.

Zanoni, B., Peri, C. \& Gianotti, R. 1995. Determination of the thermal diffusivity of bread as a function of porosity. J. Food Eng. 26(4): 497-510.

Zayas, J.F. 1997. Chapter 3: Emulsifying properties of proteins. In Functionality of Proteins in Food. Berlin Heidelberg: Springer-Verlag. pp. 134-227.

Nurul Ainaa Farhanah Mat Ramlan, Salma Malihah Mohammad, Sharifah Kharidah Syed Muhammad \& Norhasnida Zawawi* Department of Food Science

Faculty of Food Science and Technology

Universiti Putra Malaysia

43400 Serdang, Selangor Darul Ehsan

Malaysia

Roselina Karim

Department of Food Technology

Faculty of Food Science and Technology

Universiti Putra Malaysia

43400 Serdang, Selangor Darul Ehsan

Malaysia

Maznah Ismail \& Norhasnida Zawawi*

Laboratory of Molecular Biomedicine

Institute of Bioscience

Universiti Putra Malaysia

43400 Serdang, Selangor Darul Ehsan

Malaysia

*Corresponding author; email: norhasnida@upm.edu.my

Received: 3 November 2020

Accepted: 9 March 2021 